\title{
THE RELATIONSHIP BETWEEN SUPPLY CHAIN MANAGEMENT STRATEGY, MARKETING, LOGISTICS AND COMPANY PERFORMANCE FOR BREWERIES IN SERBIA
}

\author{
Dragan Ilić' , Aleksandra Tešić2
}

\begin{abstract}
Summary
The objective of this research is to demonstrate the importance of supply chain management strategy, logistics and marketing to overall company performance. We considered supply chain management strategy based on universality and integration, i.e., their company performance will be increased with implementing this strategy in breweries in Serbia. The strategy based on the universality and integration includes three parts: universality and integration with customers, suppliers, and in intra-organizational processes and activities. In this paper, logistics performance called fundamental item for evaluating supply chain management strategy performance. All managers in breweries in Serbia are considered as subjects of this study. A number of 110 managers are selected as sample through random sampling method. The present study carried out through the use of questionnaire and SPSS software, correlation statistics test and multiple regressions have also been used for the data analysis. The results of correlation test showed that supply chain management strategy has significant relationship with the logistics performance and company performance and has the highest relationship and correlation with the logistics performance. Due to the observance to the multiple regression results, we found that performance of the breweries feel the highest effect from marketing performance and marketing performance also feels the highest effect from the logistics performance and consequently, implementation of supply chain management strategy is obtained. So, it can be said that organizational performance is increased as a result of implementation of supply chain management strategy.
\end{abstract}

Key words: supply chain management, logistics, marketing, performance, breweries.

JEL: Q13, M31

1 Dragan Ilić Ph.D., Assistant Professor, University Business Academy, Faculty of Economics and Engineering Management, Cvećarska Street no. 2, 21000 Novi Sad, Serbia, Phone: +381 658539 965, E-mail: prof.dragan.ilic@gmail.com

2 Aleksandra Tešić Ph.D.,Associate Professor, University Business Academy, Faculty of Economics and Engineering Management, Cvećarska Street no. 2, 21000 Novi Sad, Serbia, Phone: +381 69 2000 954, E-mail: prof.aleksandra.tesic@gmail.com

EP 2016 (63) 4 (1157-1168) 


\section{Introduction}

The new approach which has overshadowed in the world of production and trade is based on customer and his requirements. That is to say that providers of products and services, moreover paying due attention to the quality of presented product and services, consider all activities which will result in creating value added to customer (Watson, 2002). On the other hand, production and economic institutions, moreover considering organization and internal resources, need to the management of foreign resources related to the organization. This subject is more tangible in competitive field especially for attaining high market share. Accordingly, all activities of planning supply and demand, providing materials, producing product or presenting services, preserving goods, controlling inventory and balance, distributing, delivering, etc., which were carried out previously in an organization, have been transferred to the logistics. Managing and coordinating all these activities is the key issue in a supply chain. Logistics carries out this activity in the best way, in which, customers can receive quality goods and services confidently with the appropriate speed and quality and also with the least price. But for the implementation of this activity, logistic management should be taken into consideration comprehensively. This issue should also be considered that all duties and activities, which are carried out in the length of supply chain, should be managed strategically provided that performance of all sub, individual and organizational systems should be increased (Tan, 1998). However, a comprehensive supply chain management strategy should be taken into consideration as well. A comprehensive strategy is the strategy that can bring about universality and integration internal activities of a production organization and universality and integration between extra-organizational suppliers and customers with the aim of creating value added for final customer coupled with bringing about a superior performance in terms of quality and organizational performance (Vasiljević et al., 2013). It seems undisputed that logistics constitutes a key success factor for breweries. However, in the current literature, issues relating to 'market oriented business management' are given top priority on the basis that they are about the fundamental customer orientation. Logistics is classified as a 'backroom' function and seen rather more as a 'practical' support activity (Šomođi, 2003). However, in breweries, logistics cannot validly be confined to a pure 'fulfilment' activity.

Marketing focused on demand creation and logistics was a stand-alone function supporting sales by satisfying marketing-induced demand (Angeles, Nat, 2011). This separation was implemented organisationally in the majority of firms establishing the functions as independent departments (Rinehart et al., 1989).

However, logistics and marketing are intrinsically linked because logistics entails the physical distribution of goods to customers. Therefore, efficient and flexible logistics systems can be a requirement in meeting specific customer desires. Logistics systems can be structured in such a manner as to generate significant competitive advantages. (Bešlić, 2010). However, to achieve this, logistics and marketing should not be viewed as separate functions. A strict separation may present difficulties, because the primary objectives of the individual (separated) functions may seem almost contradictory (Zentes, 2004). Coordination 
between logistics and marketing is therefore essential, and this corresponds with traditional organization theory (Lambert, Cook, 1990).

The aim of this study is to analyse the combined impact of logistics performance and marketing performance on overall company performance.

\section{Theoretical framework and background of research}

In past, managers were trying to improve performance of organization based on what had been defined within the framework of their duties merely. But supply chain managers should consider that how much organizational strategies, as used by the managers of the organization, will affect on chain participators? Because, it is possible that effort to maximize performance of organization may diminish negative effect on performance of supply chain and may increment its competitive advantage. Supply chain performance will be maximized only when we select an intra-organizational strategy, based on which, all members are cooperating with each other for maximizing chain value. Thereby, additional cost and time of one part is restored by the other part and chain performance and eventually, performance of the organization will be increased. But if each of chain members carried out their duties to maximize value of unit of their activity, the result of this activity will merely increase unnecessary costs (Chopra, Meindl, 2004). Creating value added for final customer is the main objective of supply chain management with the aim of reducing costs generally and such value added should be reflected to customers in cost, quality, flexibility and delivery of product or service which are components of supply chain (Kenneth et al., 2008). In 1997, Moorish and Clinton presented a design as a base for conducting research activities on supply chain in future. In this design, empowerment of logistics and transport established relationship between supply chain structure and its performance. Wisner (2003) assumed that there is a positive relationship between logistics strategy and organizational performance. Stank (2002) and Lin (2006) placed special emphasis on the universality of logistics processes in the length of supply chain for better meeting of customer's demands. Lai, K and Cheng (2003) emphasized on the importance of transport logistics in supply chain because, providers of logistics services establish relationship between suppliers, producers, sellers and end consumers. They state that providers of logistics services should concentrate on increasing supply chain performance, based on which, performance of the organization will be improved. Kenneth (2008) studied on the effect of supply chain management strategy on logistics performance and organizational performance. They presented a model that logistics performance was affected by supply chain management strategy, based on which, stated that supply chain management strategy and logistics performance affect financial and marketing performance. But in this study, we have used a logistics performance model for studying relationship between supply chain management strategy and organizational performance, that is, logistics performance which affected by supply chain management strategy. It should be noted that logistics performance and supply chain management strategy will affect organizational performance. The conceptual model of this study is as follows:

- Logistics performance 
- Marketing performance

- Supply Chain Management Strategy (SCM)

- Financial performance

1st Hypothesis: There is a significant relationship between supply chain management strategy and logistics performance. 2nd Hypothesis: There is a significant relationship between supply chain management strategy and marketing performance. 3rd Hypothesis: There is a significant relationship between supply chain management strategy and financial performance. 4th Hypothesis: There is a significant relationship between logistics performance and marketing performance. 5th Hypothesis: There is a significant relationship between logistics performance and financial performance. 6th Hypothesis: There is a significant relationship between marketing performance and financial performance.

Supply chain management strategy is defined to a strategy which can 1- set up universality and integration in trade activities (purchasing, producing, selling and logistics) which is carried out in the length of chain, 2- set up maximum value for end users, and for setting up this strategy, the activities should be applied that improve cooperation and confidence relation between chain participants (Cohen, Roussel, 2005 and Wisner, 2003). In this study, we state logistics performance as follows: "Ability of delivering goods and services to appropriate amount and in logical time, according to the requirement of customer." Such ability can be evaluated with customer satisfaction, delivery speed, delivery flexibility, delivery dependability) (Bowersox et al., 2000). In this study, we use five criteria of delivery speed, delivery flexibility, order full capacity, responsiveness, and delivery dependability (Kennethet al., 2008). Marketing performance shows ability of organization in increasing sales and market share growth than its rival (Green, Inman, 2005 and Green et al., 2006).

\section{Logistics and Marketing: Interdependencies and Dependencies}

In the area of marketing, the customer orientation is paramount. The objective is to align the value chain to customer needs. It is for this reason that the integrated marketing philosophy has assumed more of a relationship orientation since the 1990s (Bruhn, 2001). This has lead to the dominance of such objectives as customer satisfaction and loyalty and the long-term development of customer relationships. This orientation is expressed in the increasing importance of customer relationship management (CRM). Three dimensions describe marketing performance. Firstly, there is demand stimulation ('sales performance'), that is, the direct effect on revenue. Secondly, marketing activities attempt to encourage customers to accept price increases. This is expressed not only in an increased potential sales volume, but also in the fact that marketing activities can increase the realisable margin ('profit performance'). The third dimension ('customer performance') relates to the effect on customer satisfaction and customer loyalty. In this context, marketing measures can form long-term customer relationships which have a long-term effect on customer value to a firm. The short-term objectives of logistics are almost the opposite of the above marketing goals. 
Whereas marketing is organised primarily around customer needs, which may mean diversification, variety, flexibility and greater complexity, logistics objectives are generally to reduce complexity in order to make processes more efficient and, wherever possible, to arrive at 'simple' logistics solutions. Classic logistics solutions strive mainly towards a deterministic time series of orders and deliveries, and at improving the ability to plan and forecast. In a broader sense, marketing also opposes the 'logistics preference' for a stable time series for sales or deliveries. In order to meet customer needs to the greatest possible extent, marketing often has to destabilize the time series.

This is reflected in a variety of forms in value-added processes. A wide range of products, sales promotions, customising, and avoidance of out-of-stock situations are only a few of the relevant concepts. However, it is not simply the increased complexity resulting from the marketing perspective which contradicts logistics objectives; there are also the logistically problematic effects of the inherently stochastic nature of marketing. These effects, which are caused by marketing actions, are difficult to forecast and quite often mean that time series are not steady and can be associated with fluctuations in demand, thus causing surplus stock or out-of-stock situations.

Whereas marketing objectives (both long and short-term) are primarily aimed at increasing revenue, logistics is concerned mainly with cost reduction. Logistics solutions therefore create flexibility, speed and reliability in the supply chain. This also means that, whenever possible, simple solutions can be implemented, creating lower inventory, lower transport costs, etc. Accordingly, the implementation of efficient processes is a primary concern. Logistics performance is therefore characterised by two main dimensions: 'logistics quality' and 'logistics costs'. Logistics quality relates to the satisfaction of demand, the extent to which the right products can be delivered to the right destinations at the right time and in the right quantities ('4r') (Pugh, Hickson, 1976). The relevant logistics costs are transport and inventory costs in particular and also those related to asset commitment.

\section{Logistics Performance and Marketing Performance}

The faster and more flexible the logistics system, the more successfully customer needs are fulfilled (Zentes, 2004). Efficient logistics systems save costs, which can, in turn, be passed on to the customer. Subsequently, this has a positive influence on customer satisfaction and loyalty. Efficient logistics systems are also a prerequisite for an Everyday Low Price (EDLP) strategy, because such strategies can only be pursued where cost structures are efficient.

These examples of the chain effects demonstrate the interdependence and positive interrelationship between marketing and logistics performance. A logistics system which is optimally organised can also satisfy customer needs optimally, because there will be a rapid and flexible reaction to such needs, and out-of-stock situations will be avoided. Conversely, when marketing objectives are achieved, logistics goals can be so as well. Marketing activities do not always entail 'destabilisation' of sales. For example, EDLP-strategies usually lead to stable sales. 
Therefore, effective marketing activities can, for example, enable the avoidance of stock surpluses and their associated high capital costs, and sales can thus be stabilised.

Marketing and logistics in relation to value creation play an important role in servicing and satisfying customer needs. Marketing focuses on demand creation by adopting a certain marketing mix, whereas logistics is concerned with satisfying customer needs through optimal fulfilment of the physical conveyance of the goods. The close relationship between marketing and logistics is clearly evident and necessitates the coordination of the two functions. The benefit of an effective coordination of the marketing and logistics areas therefore seems indisputable. Even though there is a range of ECR (Efficient Consumer Response) recommendations in the literature relating to the (assumed)interrelationship, the effect of an inter-functional coordination of marketing and logistics on performance has only been analysed in a few in-depth theoretical studies (Ellinger et al., 2000).

The benefits of an intra-organisational coordination of marketing and logistics may result from variety of different considerations. In this context, inter-functional interaction between the areas is the most important. Formally regulated collaboration, for example, information exchange, leads to quantitatively and qualitatively better information being available for marketing and logistics decisions(Ellinger et al., 2000). Coordination reduces complexity and uncertainty, has a positive effect on the quality of the decision making process and improvesaccording to information processing theory - the information processing capacity of the company. Consequently, it has a positive effect on marketing and logistics performance.

At the primarily inter-personal, often informal level, communication also exerts a positive influence on the relationship between those two areas. Intra-organisational communication between marketing and logistics creates trust, particularly at a personal level between staff members. This improves marketing and logistics performance and subsequently the overall performance of the breweries. All in all, a positive relationship between the coordination of marketing and logistics and the performance of these areas may be assumed.

\section{Inter-organisational Coordination of Logistics and Marketing}

In the context of inter-organisational approaches to marketing and logistics coordination of different players within the value chain, the approaches of ECR are particularly relevant. ECR is central to the development of concepts for exploiting inter-organisational potential through the structuring and control of value chains for supply chain management and category management.

These approaches are aimed at inefficiencies which can occur when each single valueadded partner is considered in isolation. Inefficiencies of this type, which can result from the isolated planning of materials or order quantities along the value chain, is characterised by the 'bullwhip effect'. This occurs when sales or order quantity fluctuations swing upwards through the various value-added stages, with the amplitudes increasing at each stage. The effect demonstrates how pervasive inefficiencies can arise mainly from delays caused by uncoordinated planning cycles, inconsistent and possibly out-of-date customer information or sales data. This then impacts on planning and reduces the transparency of supply and 
materials quantities beyond the specific value-added stage. The main approach to solving these difficulties is the implementation of comprehensive inter-organisational information and planning systems, allowing an information flow which reduces inefficiency.

In a similar manner to data flow at the intra-organisational level, data flow between manufacturer and retailer is also associated with a better quality of data at the various stages of the value chain when the appropriate systems are in place. This quality enhancement results mainly from both a broader database and more comprehensive information from a variety of perspectives, i.e., manufacturer and retailer, marketing and logistics information. The coordination and transparency yielded by the information flow have a positive effect on overall company performance (Angeles, Nath, 2001).

Value-added partners need information from both marketing and logistics in order to achieve intra and inter-organisational coordination. Inter-functional integration is therefore a requirement for the successful provision and processing of information, as well as for effective decision-making processes. Conversely, the information and data yielded by interorganisational coordination processes also assists internal coordination by providing targetoriented information for both areas.

External and internal coordination establish coordination and relationship expertise. This expertise and information can be used as the basis for new coordination processes and to support existing processes.

\section{Empirical Study}

In this paper, measurement tool is the questionnaire which has been designed and compiled by Kenneth and et al in 2008. Since validity and reliability of evaluation tool in each study were necessary, survey was taken from researchers and thinkers in the field of researching with relation to the accuracy rate and transparency of questions in questionnaires to take into consideration of validity of questionnaire. A written survey of 110 randomly selected managers in brewing companies, using a standardised questionnaire, was conducted in the second half of 2015. The questionnaire was sent by mail or email. It could be completed as a paper hard copy and returned by mail, completed in a PDF document and returned by e-mail, or done online (online questionnaire). By the beginning of December 2015, 92 questionnaires had been returned ( 70 per mail, 22 online). Of these, 5 had to be rejected, so that a total of 87 questionnaires remained which could be used for the investigation.

The measurement model was evaluated using the empirical data. Cronbach's Alpha Coefficient method was used for the measurement of reliability. Thus, alpha was calculated through the application of SPSS software after presentation of 20 questionnaires as protest. Based on the obtained results, reliability coefficient of the questionnaire stands at above 0.7 thanks to the variables which shows that the specified questionnaire enjoys enough stability and reliability.

Due to the observance to the methodology, analysis of research questions of the study is related to the correlation method which was carried out in two inferential and descriptive 
statistics levels. In descriptive section, statistical analysis such as frequencies and percent was used. In inferential statistics, Pearson Correlation Coefficient, Coefficient of Determination, Multivariate Regression Analysis was used thanks to the nature and level of measurement of variables (relative, nominal, ordinal and distance). Since model of this research is of a structural equation model, Path Analysis Method was used for evaluating it. It should be noted that Path Analysis Method is a technique which enable us to comprehend relative significance of direct and indirect bonds and neutrality of the model with a set of data as well. This study follows two aims: 1- Identifying existence of relationship, 2- setting direction, severity and type of relationship between variables. Significant level has been considered $\alpha=0.01$ for all hypotheses.

In this way the theoretical assumptions (hypotheses) are empirically tested and confirmed in the research undertaken on brewing industry in Serbia.

\section{Analysis of Empirical Results}

Beginning with the relationship between marketing and logistics performance, the correlations between all sub-dimensions of marketing and logistics performance are positive and significant (Table 1.). Overall, based on the results, a positive reciprocal relationship between marketing and logistics performance is obvious.

Table 1.Correlations between logistics performance and marketing performance

\begin{tabular}{|c|c|c|c|}
\hline & Sales Performance & Profit Performance & Customer Performance \\
\hline Logistics Quality & $.271^{* *}$ & $.144^{* *}$ & $.521^{* *}$ \\
\hline Logistics Costs & $.113^{* *}$ & $.356^{* *}$ & $.386^{* *}$ \\
\hline
\end{tabular}

Note:**Significant to .01 level

Source: Authors'research

The analysis of the effect of marketing performance and logistics performance on that of the company as a whole, also reveals a positive influence of these performance dimensions on overall company performance (Table 2.).

Regarding the influence of marketing performance on overall company performance, it is firstly clear that the respective dimensions merely have an effect on the dimension of company performance. Thus, sales and profit performance have a predictably greater effect on company performance, whereas 'customer performance' (which is particularly well aligned to customer needs) mainly influences the ability of a company to adapt to market forces and to innovate successfully. As a whole, the influence of logistics performance on company performance appears to be particularly important. Thus, the effects of logistics quality and logistics costs have a significant impact on overall company performance. Logistics is an important influence factor on the competitiveness of a company. Furthermore, it also has comparatively high influence on company's flexibility. 
Table 2. Effect of marketing and logistics performance on company performance

\begin{tabular}{|l|r|}
\hline \multicolumn{1}{|c|}{ Relationship } & \multicolumn{2}{c|}{ Standardized path coefficients } \\
\hline Sale performance-financial performance & $.601^{* *}$ \\
\hline Sale performance-flexibility & -.011 (n.s.) \\
\hline Profit performance-financial performance & $.308^{* *}$ \\
\hline Profit performance-flexibility & .001 (n.s.) \\
\hline Customer performance-financial performance & -.050 (n.s.) \\
\hline Customer performance-flexibility & $.657^{* *}$ \\
\hline Logistics quality-financial performance & $.564^{* *}$ \\
\hline Logistics quality-flexibility & $.311^{* *}$ \\
\hline Logistics costs -financial performance & $.412^{* *}$ \\
\hline Logistics costs -flexibility & -.060 (n.s.) \\
\hline
\end{tabular}

Note:*Significant to .01 level, (n.s.) - not significant

Source: Authors'research

\section{Conclusions and Implications for Future Research}

The results, showed that chain management strategy has established significant relationship with each of three types of performance (financial, marketing and logistics). Relationship and correlation with the organizational performance $(0 \mathrm{r}=0.469)$ and marketing performance $(\mathrm{r}=$ $0.425)$ is found "weaker" but it is found "more" with the logistics performance $(\mathrm{r}=0.535)$ Also, logistics performance has significant relationship with the company performance (financial and marketing). With due observance to the Beta coefficient in multivariate regression, it has left the highest effect on marketing performance. It should be noted that marketing performance leaves the highest effect on company performance and correlation is very high between these two variables. $(r=0.713)$ The results, obtained from model analysis through the use of Path Analysis Method, showed that model enjoys fair fitting. With the calculation of variables' direct and indirect effects, it was specified that the highest effect is related to the marketing performance variable which affects financial performance. The results obtained from correlation coefficient and multivariate regression coefficient showed authenticity of the last issue. Marketing performance accepts the highest effect from logistics performance thanks to the results obtained from multivariate regression analysis and a superior logistics performance is originated from implementation of supply chain management strategy. Implementation of supply chain management strategy results in improvement of logistics performance, based on which, marketing performance will be affected. Since logistics performance has been considered as a basis of evaluation of supply chain management strategy, providers of logistics services should concentrate on increasing supply chain performance. Consequently, performance of the organization will be increased. By the way, quality goods and services can be presented according to the requirement of customers appropriately in the shortest time possible and with fair price through implementation of a strategy based on universality and integration with customers and suppliers, processes and activities, and implementation of those activities which improve and intensify cooperation and trust relationship among participants. At last, marketing performance is the most important 
variable affecting financial performance of companies. It should be noted that marketing performance is severely affected by the logistics performance as a result of implementation of supply chain management strategy. Thus, making decision and implementing an appropriate chain management strategy is vital for managers of production companies.

While the findings of this general study mainly support previous research, additional contributions do, nonetheless, emerge from integrating the aspects of intra- and interorganisational coordination of marketing and logistics in one study and the analysis of the interdependencies between these aspects, which are supported in the brewing business context. There are other useful implications which go beyond previous research. First, the high strategic relevance of logistics performance on long-term aspects of marketing performance (e.g., customer satisfaction and loyalty) is shown to be highly significant. This goes beyond the classification of logistics as a 'fulfilment' activity for sales and it also goes beyond efficiency goals, on which a large number of optimizing approaches (especially at the inter-organizational level, e.g., ECR-approaches) are focused. Whereas cost reductions through logistics optimization can be achieved in the short term and investment in these areas often delivers quick returns and is prevalent in the investment strategy of retail companies in practice, the strategic importance of logistics for marketing performance becomes clear in this study.

These results are particularly useful, given that, in previous research, the areas of integration were usually analyzed at a general level or separately, and the implicit assumption was usually that the integration of marketing activities should be of at least similar importance for marketing performance at the inter-organisational level.

\section{Literature}

1. Angeles, R., Nath, R. (2001):Partner congruence in Electronic Data Interchange(EDI)enabled relationships, Journal of Business Logistics, vol. 22, no. 2, pp. 109-127.

2. Bešlić, I., Bešlić, D. (2010): Measuring performance in a production company as a source of competitive advantage, Economics of Agriculture, vol. 57, no. 2, pp. 313-326.

3. Bowersox, D.J., Closs, D.J., Stank, T.P ., Keller, S.B. (2000):How Supply Chain Competency Leads to Business Success. Supply Chain Management Review, vol. 4, no. 4, pp. 70-80.

4. Bruhn, M. (2001):Relationship Marketing, Munchen: Vahlen.

5. Chopra, S., Meindl, P. (2004):Supply Chain Management: Strategy, Planning, and Operation, 2nd Edition, Pearson Prentice -Hall, Upper Saddle River, NJ.

6. Ellinger, A. E., Daugherty, P. J., Keller, S. B. (2000):The relationship between marketing/ logistics inter department integration and performance in US manufacturing firm, Journal of Business Logistics, vol. 21, no. 1, pp. 1-22.

7. Fuente,M.V.,Rosa, L.,Cardos, M. (2008): Integrating Forward and Reverse Supply Chains: Application to a Metal-Mechanic Company, International Journal of Production Economics, vol. 111, no. 2, pp. 782-792.

8. Green, K.W. Jr, Inman, R.A. (2005): Using a Just In Time selling strategy to strengthen supply chain linkages, International Journal of Production Research vol. 43, no. 16, pp. 
3437-3453.

9. Green, K.W. Jr., McGaughey, R., Casey, K.M. (2006): Does Supply Chain Management Strategy Mediate the Association Between Market Orientation and Organizational Performance?, Supply Chain Management: An International Journal, vol. 11, no. 5, pp. 407-414.

10. Green, K.W. Jr., Medlin, B., Whitten, D. (2004): Developing Optimism to Improve Performance: An Approach for the Manufacturing Sector, Industrial Management and Data Systems, vol. 104, no. 2, pp. 106-114.

11. Green, K.W.Jr. (2008): The Impact of Logistics Performance on Organizational Performance in a Supply Chain Context, Emerald Group Publishing Limited, pp. 317327.

12. Lai, K., Cheng, T.C.E., (2003): Supply chain performance in transport logistics: An Assessment by Service Providers, International Journal of Logistics Research and Applications ,vol. 16, no. 3, pp. 152-164.

13. Lambert, D. M., Cook, R. L. (1990): Integrating marketing and logistics for increased profit, Business, vol. 40, no. 3, pp. 22-29.

14. Lin, C. (2006): Influencing Factors on the Innovation in Logistics Technologies for Logistics Service Providers in Taiwan, Journal of American Academy of Business, vol. 9, no. 2, pp. 257-263.

15. Morash, E.A., Clinton,S.R. (1998): Supply Chain Integration: Customer Value Through Collaborative Closeness Versus Operational Excellence. Journal of Marketing: Theory and Practice, vol. 6, no. 4, pp. 104-120.

16. Pugh, D. S., Hickson, D. J. (1976): Organizational Structure in its Context (Westmead: The Aston Programme I).

17. Rinehart, L. M., Cooper, M. B.,Wagenheim, G. D. (1989):Furthering the integration of marketing and logistics through customer service in the channel, Journal of the Academy of Marketing Science, vol. 17, no. 1, pp. 63-71.

18. Stank, T.P., Keller, S.B., Closs, D.J. (2002): Performance Benefits of Supply Chain Logistical Integration, Transportation Journal, no. 41, pp. 32-46.

19. Šomođi, Š. (2003): Logistics, integration, cooperation in food production, Economics of Agriculture, vol. 50, no. 4, pp. 335-349.

20. Tan, K.C., Kannan, V.R.,Handfield, R.B., (1998):Supply Chain Management: Supplier Performance and Firm Performance International, Journal of Purchasing and Materials Management, vol. 34, no. 3, pp. 2-9.

21. Zentes, J. (2004): Marketing-effektivitat vs. logistik-effizienz, Theoretischeuberlegungen und empirischebefunde, pp. 255-270, Heidelberg, Deutschland.

22. Vasiljević, D., Stepanović, M., Manojlović Oliver (2013): The application of the concept of cross-docking in the distribution of food products, Economics of Agriculture, vol. 60, no. 1, pp. 91-101.

23. Watson, H. (2002):Delivering Value to Customers, Quality Progress 


\title{
ODNOS IZMEĐU STRATEGIJE UPRAVLJANJA LANCEM \\ SNABDEVANJA, MARKETINGA, LOGISTIKE I PERFORMANSI \\ KOMPANIJE U SRPSKIM PIVARAMA
}

\author{
Dragan Ilič̉, Aleksandra Tešićc
}

\begin{abstract}
Rezime
Cilj ovog istraživanja je da se demonstrira značaj strategije upravljanja lancem snabdevanja, logistike i marketinga na ukupne performanse pivara u Srbiji. Razmatrali smo strategiju upravljanja lancem snabdevanja baziranu na univerzalnosti i integraciji, to jest performanse pivara u Srbiji će se povećati sprovođenjem ove strategije. Strategija zasnovana na univerzalnosti i integraciji uključuje tri dela: univerzalnost i integracije sa kupcima, dobavljačima i unutar-organizacionih procesa i aktivnosti. U ovom radu, logističke performanse se smatraju fundamentalnim za procenu performansi strategije upravljanja lancem snabdevanja. Svi rukovodioci u pivarama u Srbiji posmatrani su kao subjekti ovog istraživanja. Ukupno 110 menadžera su izabrani kao uzorak metodom slučajnog uzorka. Ova studija sprovedena je upotrebom upitnika i SPSS programa, dok su korelaciona analiza $i$ metoda višestruke regresije korišćene za analizu podataka. Rezultati korelacione analize pokazali su da strategija upravljanja lancem snabdevanja ima značajnu vezu sa logističkim performansama $i$ performansama pivara, a ima najveću povezanost sa logističkim performansama pivara u Srbiji. Posmatranjem rezultata višestruke regresije, ustanovili smo da performanse pivara osećaju najjači efekat od strane marketing performansi, a marketing performanse osećaju najjači efekat od strane logističkih performansi i posledično taj efekat se dobija primenom strategije upravljanja lancem snabdevanja. Dakle, može se reći da su performanse pivara u Srbiji povećane kao rezultat implementacije strategije upravljanja lancem snabdevanja.
\end{abstract}

Ključne reči: upravljanje lancem snabdevanja, logistika, marketing, performanse, pivare.

3 Docent, dr Dragan Ilić, Univerzitet Privredna akademija, Fakultet za ekonomiju i inženjerski menadžment, Ulica Cvećarska br. 2, 21000 Novi Sad, Srbija, Telefon: +381 65 8539 965, E-mail: prof.dragan.ilic@gmail.com

4 Vanredni profesor, dr Aleksandra Tešić, Univerzitet Privredna akademija, Fakultet za ekonomiju i inženjerski menadžment, Ulica Cvećarska br. 2, 21000 Novi Sad, Srbija, Telefon: +381 692000 954, E-mail: prof.aleksandra.tesic@gmail.com 